\title{
PENGARUH MODEL PEMBELAJARAN QUANTUM LEARNING BERBANTUAN PETA PIKIRAN TERHADAP KEMAMPUAN BERPIKIR KREATIF DAN HASIL BELAJAR IPS SISWA KELAS V
}

\author{
I Kadek Rusadi Putra ${ }^{1}$, Ni Wayan Rati ${ }^{1}$, I Nyoman Murda ${ }^{2}$ \\ Prodi Pendidikan Guru Sekolah Dasar,Universitas Pendidikan Ganesha Singaraja \\ e-mail: rusadiputra29@gmail.com¹, niwayan.rati@undiksha.ac.id ${ }^{1}$, inyoman.murda@undiksha.ac.id²
}

\begin{abstract}
Abstrak
Rata-rata nilai pengetahuan IPS siswa kelas $\mathrm{V}$ tergolong rendah. Hal ini disebabkan oleh kurangnya penggunaan model dan media pembelajaran yang inovatif dan menyenangkan oleh guru dalam proses pembelajaran di kelas. Oleh karena itu, penelitian ini bertujuan untuk mengetahui pengaruh model pembelajaran Quantum Learning berbantuan peta pikiran terhadap (1) kemampuan berpikir kreatif (2) hasil belajar IPS (3) kemampuan berpikir kreatif dan hasil belajar IPS siswa kelas V SD gugus III Kecamatan Tembuku Kabupaten Bangli tahun pelajaran 2018/2019. Penelitian ini merupakan penelitian eksperimen semu (quasi experiment) dengan desain nonequivalent posttest only control group. Populasi dalam penelitian ini berjumlah 237 yang merupakan seluruh siswa kelas $\mathrm{V}$ di gugus III Kecamatan Tembuku, sedangkan sampel penelitian berjumlah 25 orang pada kelas V SD Negeri 5 Peninjoan sebagai kelompok eksperimen dan siswa kelas V SD Negeri 1 Peninjoan sebagai kelompok kontrol berjumlah 25 orang. Pengumpulan data variabel kemampuan berpikir kreatif menggunakan tes essay dan variabel hasil belajar IPS menggunakan tes pilihan ganda. Hipotesis pada penelitian ini diuji dengan menggunakan teknik analisis multivarians (Manova). Hasil Penelitian menunjukan bahwa (1) terdapat pengaruh model pembelajaran Quantum Learning berbantuan peta pikiran terhadap kemampuan berpikir kreatif $(F=16,585 p=0,000<0,05)$, (2) terdapat pengaruh model pembelajaran Quantum Learning berbantuan peta pikiran terhadap hasil belajar IPS ( $F=37,394 p=0,000<0,05)$, (3) secara simultan terdapat pengaruh model pembelajaran Quantum Learning berbantuan peta pikiran terhadap kemampuan berpikir kreatif dan hasil belajar IPS $(p=0,000<0,05)$.
\end{abstract}

Kata Kunci: quantum learning berbantuan peta pikiran, berpikir kreatif, hasil belajar IPS

\begin{abstract}
The average grade of social science knowledge of five grade students is low. This is caused by the lack of use of innovative and fun models and learning media by teachers in the learning process in the classroom. Therefore, The current study was intended to find out effect of Quantum Learning with mind mapping in (1) creative thinking (2) social learning achievement (3) creative thinking and social learning achievement of five grade students in SD Gugus III Tembuku, Bangli in academic year 2018/2019. This study was a quasiexperiment with nonequivalent posttest only control group design. The population of this study were all of five grade students in SD Gugus III Tembuku, Bangli with 237 students and the sampel of this study were all of five grade students in SD Negeri 5 Peninjoan with 25 students. The students in SD Negeri 5 Peninjoan was an experiment group and student in SD Negeri 1 Peninjoan was a control group with 25 students. The data of creative thinking were collected with essay test and the data for social learning achievement were colleted with multiple choice test. The hipotesis of the study that analys with multivarians (Manova). It was found that (1) there was significant difference of Quantum Learning with mind mapping and creative thinking ( $(F=16,585 p=0,000<0,05)$, (2) there was significant difference of Quantum Learning with mind mapping and social learning achievement $(F=37,394 p=0,000<0,05)$, (3) simultaneously, there was significant difference of Quantum Learning with mind mapping on students' creative thinking and social learning achievement $(p=0,000<0,05)$.
\end{abstract}

Keywords: quantum learning with mind mapping, creative thinking, social learning achievement 
PIPS, Vol. 3 No. 1, Bulan April Tahun 2019

ISSN:2614-8366

\section{PENDAHULUAN}

Pendidikan merupakan usaha sadar untuk menyiapkan peserta didik dalam menghadapi dan mengantisipasi kehidupan masyarakat di masa depan. Sanjaya (2006) mengemukakan berbagai upaya untuk meningkatkan mutu pendidikan telah dilaksanakan mulai dari pelatihan peningkatan kualitas guru, penyempurnaan kurikulum, serta penyediaan sarana dan prasarana yang dapat menunjang mutu pendidikan, hal ini bertujuan agar proses pembelajaran di sekolah dapat berjalan secara optimal. IImu pengetahuan Sosial (IPS) merupakan salah satu mata pelajaran yang diajarkan di sekolah dasar (SD). Susanto (2013) megemukakan bahwa pendidikan IPS di sekolah dasar merupakan bidang studi yang mempelajari manusia dalam semua aspek kehidupan dan interaksi dalam masayarakat. IPS sebagai mata pelajaran di SD memiliki tujuan untuk membantu siswa mengetahui perannya sebagai salah satu anggota masayarakat, mengembangkan potensi agar peka terhadap masalah sosial, serta sebagai warga negara baik dan bertanggung jawab. Nur Hadi (dalam Utami Munandar, 2004:146), "menyebutkan ada 4 tujuan pendidikan IPS, yaitu: pengetahuan (knowledge), keterampilan (skills), sikap dan nilai (attitudes and values)". Dari Tujuan tersebut diharapkan pendidikan IPS dapat digunakan untuk mengenal diri mereka sendiri sebagai kemampuan untuk memecahkan masalah pribadi atau masalah sosial serta kemampuan mengambil keputusan dan berpartisipasi dalam berbagai kegiatan kemasyarakatan agar menjadi warga negara yang baik. Kenyataan yang terjadi Darmayoga (2013) beranggapan banyak yang menganggap bahwa IPS merupakan pelajaran tidak menarik, peserta didik tidak memperoleh sesuatu yang dapat disimpan dalam memorinya, sulitnya mengingat materi yang cukup banyak, dan sebagaian besar siswa mempelajari materi dengan cara menghafal.

Ketika dilakukan wawancara bersama dengan sebagian besar guru kelas pada tanggal 07 dan 08 Januari 2019 di SD yang ada di Gugus III Kecamatan Tembuku, Kabupaten Bangli diperoleh hasil yaitu 1) masih banyak siswa yang mengalami kesulitan dalam pembelajaran IPS, 2), kemampuan berpikir kreatif siswa dalam pembelajaran IPS masih kurang. Selain wawancara bersama guru kelas juga dilakukan observasi ditemukan beberapa masalah terkait dengan pembelajaran yaitu: (1) Guru cenderung menggunakan metode ceramah, penugasan, dan tanya jawab dalam pembelajaran, (2) jarangnya penggunaan model pembelajaran yang inovatif dan menyenangkan oleh guru dalam proses pembelajaran di kelas, (3) Saat proses pembelajaran IPS banyak siswa yang tidak memperhatikan penjelasan guru, hal ini menggambarkan bahawa kurangnya motivasi siswa dalam pembelajaran IPS, (3) kurangnya inovasi guru dalam penggunaan media pembelajaran khususnya dalam pembelajaran IPS, (4) siswa kurang melatih keterampilan berpikir kreatif, dilihat dari kurang aktif siswa dalam meberikan pendapatnya pada saat proses pembelajaran berlangsung dalam pembelajaran IPS. Selain itu rendahnya hasil belajar siswa juga dapat dilihat dari rata-rata nilai ulangan akhir semester (UAS) siswa masih banyak siswa yang mendapat nilai dibawah KKM. Kondisi demikian apabila dibiarkan akan berdampak kurang baik terhadap kualitas pembelajaran IPS di SD Gugus III Kecamatan Tembuku, Kabupaten Bangli. Alangkah baiknya bila guru di SD Gugus III Kecamatan Tembuku, Kabupaten Bangli menerapakan berbagai model pembelajaran yang bervariasi sehingga melibatkan siswa secara aktif dan menyenangkan.

Model Pembelajaran yang dapat menciptakan suasana menyenangkan salah satunya adalah Model Quantum Learning. "Model Quantum Learning adalah kiat-kiat, petunjuk, strategi, dan seluruh proses belajar yang dapat mempertajam pemahaman dan daya ingat, serta membuat belajar sebagai suatu proses yang menyenangkan dan bermanfaat" (Thobroni, 2015:221). Dengan menggunakan Model Quantum Learning peserta tidak hanya tentang apa yang di pelajari namun menekankan untuk memberikan maanfaat yang bermakna dan juga menekankan pada tingkat kesenangan dari peserta didik. Selain menggunakan model Quantum Learning untuk meningkatkan kemampuan berpikir kreatif dan hasil belajar pelajaran IImu Pengetahuan Sosial Siswa, agar lebih optimal dipadukan dengan media peta pikiran (mind mapping). Buzan (dalam Purnamiati, 2017) menyatakan bahwa peta pikiran (mind mapping) dapat dibandingkan dengan peta kota, dimana pusat peta pikiran (mind mapping) mirip dengan pusat kota. Pusat mind map mewakili ide terpenting dan jalan-jalan utama yang menyebar dari pusat mewakili pikiran-pikiran utama dalam proses pemikiran kita. Jalan-jalan sekunder mewakili pikiran-pikiran sekunder dan 
seterusnya. Darmayoga (dalam Purnamiati, 2017) menyebutkan beberapa manfaat mind mapping diantaranya (1) memberi pandangan menyeluruh terkait pokok masalah atau area yang luas, (2) memungkinkan kita merencanakan rute atau membuat pilihan-pilihan dan mengetahui ke mana kita akan pergi dan dimana kita akan berada, (3) mengumpulkan sejumlah besar data di suatu tempat, (4) mendorong memecahkan masalah dengan membiarkan kita melihat jalan-jalan terobosan kreatif baru, (5) menyenangkan untuk dilihat, dibaca, dicerna dan diingat.

Kerangka rerancangan belajar Quantum Learning terdiri atas 8 tahap yaitu, 1) kekuatan ambak, pada tahap ini dilakukan dengan memberikan motivasi, 2) penataan lingkungan belajar, pada tahap ini membuat siswa merasa aman dan nyaman, 3) memupuk sikap juara, dengan memberikan pujian, 4) membebaskan gaya belajar, memberikan gagasan kepada siswa dalam belajar untuk menggali informasi, 5) membiasakan mencatat, mengungkapkan kembali apa yang diperoleh dengan menggunakan bahasa sendiri, 6) membiasakan membaca, tahap ini meningkatkan pemahaman bahasa dan wawasan, 7) menjadikan anak lebih kreatif, hal ini dapat menemukan rasa ingin tahu dan memungkinkan siswa menghasilakn ide-ide yang segar, 8) melatih kekuatan memori, tahap ini dapat meningkatkan kemampuan daya ingat peserta didik.

Berdasarkan uraian permasalahan yang telah dipaparkan, maka dilakukan penelitian yang berjudul Pengaruh Model Pembelajaran Quantum Learning Berbantuan Peta Pikiran Terhadap Kemampuan Berpikir Kreatif dan Hasil Belajar Siswa Kelas V.

\section{METODE}

Penelitian ini dilaksanakan di VIII di SD Gugus III Kecamatan Tembuku, Kabupaten Bangli yang terdiri dari 8 kelas dalam 8 Sekolah Dasar Negeri. Penelitian ini merupakan eksperimen semu (quasi eksperimen) terhadap siswa-siswa dalam suatu kelas.

Populasi dari penelitian ini adalah seluruh siswa kelas V di SD Gugus III Kecamatan Tembuku, Kabupaten Bangli yang terdiri dari 8 kelas dalam 8 Sekolah Dasar Negeri. Jumlah populasi dari penelitian ini adalah 237 siswa, jumlah siswa pada setiap sekolah dapat dilihat pada Tabel 01.

Tabel 01. Tabel Populasi Siswa Kelas V SD Gugus III Kecamatan Tembuku Tahun Ajaran 2018/2019

\begin{tabular}{llll} 
No & Nama Sekolah & Kelas & $\begin{array}{l}\text { Jumlah } \\
\text { Siswa }\end{array}$ \\
\hline $\mathbf{1}$ & SDN 1 Peninjoan & V & 25 \\
\hline $\mathbf{2}$ & SDN 5 Peninjoan & V & 25 \\
\hline $\mathbf{3}$ & SDN 6 Peninjoan & V & 18 \\
\hline $\mathbf{4}$ & SDN 1 Yangapi & V & 39 \\
\hline $\mathbf{5}$ & SDN 2 Yangapi & V & 43 \\
\hline $\mathbf{6}$ & SDN 4 Yangapi & V & 14 \\
\hline $\mathbf{7}$ & SDN 5 Yangapi & V & 44 \\
\hline $\mathbf{8}$ & SDN 6 Yangapi & V & 29 \\
\hline Total & & & 237 \\
\hline
\end{tabular}

Penentuan sampel menggunakan teknik random sampling dengan menggunakan teknik undian. Seluruh kelas tersebut diundi untuk menentukan kelas eksperimen dan kelas kontrol. Undian yang dilakukan yaitu menulis semua kelas V di SD Gugus III Kecamatan Tembuku Kabupaten Bangli dalam kertas kecil, kemudian kemudian digulung. Selanjutnya diambil gulungan kertas pertama yang akan dijadikan sebagai kelas eksperimen dan gulungan kedua sebagai kelas kontrol. Berdasarkan pengundian untuk memperoleh kelas eksperimen dan kelas kontrol, diperoleh sampel yaitu siswa kelas V SDN 5 Peninjoan sebagai kelompok eksperimen dan seluruh siswa kelas $V$ di SDN 1 Peninjoan sebagai kelompok kontrol.

Dalam penelitian ini Untuk mengumpulkan data mengenai kemampuan berpikir kreatif digunakan adalah dengan menggunakan tes essay berpikir kreatif yang terdiri dari beberapa dimensi yaitu kelancaran (fluency), keluwesan (flexibility), keaslian (originality), penguraian 
(elaboration). Sedangkan untuk pengumpulan data hasil belajar IPS digunakan tes obyektif pilihan ganda.

Kegiatan analisis data terdiri atas kegiatan pengolahan data dan analisis statistik. Data yang dikumpulkan dalam penelitian ini adalah data kemampuan berpikir kreatif dan data hasil belajar IPS siswa kelas V. Dalam penelitian ini digunakan analisis varian yang disingkat Manova. "Uji Manova digunakan untuk menguji apakah terdapat perbedaan beberapa variabel terikat antara beberapa kelompok yang berbeda" (Candiasa, 2010:39). Variabel bebas dalam penelitian ini adalah model pembelajaran Quantum Learning berbantuan peta pikiran dengan dua variabel terikat yaitu kemampuan berpikir kreatif dan hasil belajar IPS. Data hasil penelitian yang telah dikumpulkan akan dianalisis secara bertahap yakni deskripsi data, uji prasyarat analisis dan uji hipotesis. Adapun uji prasyarat yang dilakukan adalah uji normalitas sebaran data, uji homogenitas varians, dan uji korelasi antar variabel terikat.

\section{HASIL DAN PEMBAHASAN}

Deskripsi data dikelompokan menjadi 4, yaitu: (1) kemampuan berpikir kreatif siswa yang mengikuti model pembelajaran Quantum Learning berbantuan peta pikiran , (2) hasil belajar IPS siswa yang mengikuti model pembelajaran Quantum Learning berbantuan peta pikiran, (3) kemampuan berpikir kreatif siswa yang tidak dibelajarkan model pembelajaran Quantum Learning berbantuan peta pikiran, (4) hasil belajar IPS siswa yang tidak dibelajarkan model pembelajaran Quantum Learning berbantuan peta pikiran. Deskripsi data meliputi pengukuran rata-rata hitung, median, modus, standar deviasi, range, nilai minimum, dan nilai maksimum. Berikut adalah penyajian rangkuman statistik deskriptif untuk memudahkan mendiskripsikan masing-masing variabel.

Tabel 02. Rangkuman Statistik Deskriptif Variabel Penelitian

\begin{tabular}{ccccc}
\hline \multirow{2}{*}{ Statistik } & \multicolumn{2}{c}{$\begin{array}{c}\text { Kemampuan Berpikir } \\
\text { Kreatif }\end{array}$} & \multicolumn{2}{c}{ Hasil Belajar IPS } \\
& $\begin{array}{c}\text { Eksperimen } \\
\text { N }\end{array}$ & Kontrol & Eksperimen & Kontrol \\
\hline Mean & 17,00 & 13,48 & 18,68 & 13,04 \\
\hline Median & 18,14 & 13,71 & 19,85 & 12,57 \\
\hline Modus & 19,3 & 13,8 & 21 & 10,75 \\
\hline Standar Deviasi & 3,16 & 2,94 & 3,27 & 3,24 \\
\hline Range & 11 & 10 & 11 & 11 \\
\hline
\end{tabular}

Berdasarkan Tabel 02 di atas dapat disimpulkan bahwa, (1) kemampuan berpikir kreatif siswa yang mengikuti model pembelajaran Quantum Learning berbantuan peta pikiran berada pada kategori tinggi , (2) hasil belajar IPS siswa yang mengikuti model pembelajaran Quantum Learning berbantuan peta pikiran berada pada kategori tinggi, (3) kemampuan berpikir kreatif siswa yang tidak dibelajarkan model pembelajaran Quantum Learning berbantuan peta pikiran berada pada kategori sedang, (4) hasil belajar IPS siswa yang tidak dibelajarkan model pembelajaran Quantum Learning berbantuan peta pikiran berada pada kategori sedang. Sebelum dilakukan pengujian hipotesis, terlebih dahulu dilakukan uji prasyarat analisis yang meliputi uji normalitas sebaran data hasil perhitungan post-test kelompok eksperimen dan kontrol dengan menggunakan SPSS 17.0, dari output analisis menunjukkan nilai kolmogrov Smirnov (a) berpikir kreatif adalah 0,192 dan 0,200 sedangkan nilai dari hasil belajar adalah 0,200 dan 0,181. Oleh karena itu nilai probabilitas kedua nilai signifikan $>0,05$, maka data hasil post-test kelompok eksperimen dan kontrol berdistribusi normal. Uji prasyarat yang kedua yaitu, uji homogenitas varians hasil analisis menunjukan bahwa angka signifikan yang dihasilkan secara terpisah lebih besar dari 0,05. Dengan demikian dapat disimpulkan bahwa variabel berpikir kreatif dan hasil 
belajar adalah homogen. Uji prasyarat yang ketiga yaitu, uji korelasi antar variabel terikat menggunakan uji product moment menunjukkan rxy hitung sebesar 0,00 , dengan $\mathrm{N}=25$ dan df $=$ 23, sehingga didapat rxy tabel $=0,413$. Hal ini berarti, rxy hitung lebih kecil dari rxy tabel (rxy hitung $=0,00<$ rxy tabel $=0,413$ ), sehingga dapat disimpulkan bahwa antara variabel berpikir kreatif dan variabel hasil belajar pada kelompok eksperimen tidak berkorelasi. Pada kelompok kontrol, hasil uji product moment menunjukkan rxy hitung sebesar 0,00 , dengan $\mathrm{N}=25$ dan df $=$ 23 , sehingga didapat rxy tabel $=0,413$. Hal ini berarti, rxy hitung lebih kecil dari rxy tabel ( $r x y$ hitung $=0,00<$ rxy tabel $=0,413$ ), sehingga dapat disimpulkan bahwa antara variabel kemampuan berpikir kreatif dan variabel hasil belajar IPS pada kelompok tidak berkorelasi.

Selanjutnya melakukan uji hipotesis menggunakan uji (Manova). Hipotesis yang pertama melakukan analisis data model pembelajaran Quantum Learning berbantuan peta pikiran (X) terhadap kemampuan berpikir kreatif $\left(Y_{1}\right)$, hasil analisis data dapat dilihat pada Tabel 03.

Tabel 03. Tests of Between-Subjects Effects

\begin{tabular}{|l|c|c|c|c|c|}
\hline $\begin{array}{c}\text { Dependent } \\
\text { Source Variable }\end{array}$ & $\begin{array}{c}\text { Type III } \\
\text { Sum of } \\
\text { Squares }\end{array}$ & Df & $\begin{array}{c}\text { Mean } \\
\text { Square }\end{array}$ & F & Sig. \\
\hline $\begin{array}{l}\text { Correct Berpikir } \\
\text { ed Kreatif } \\
\text { model }\end{array}$ & 154.880 & 1 & 154.880 & 16.585 & .000 \\
\hline
\end{tabular}

Tabel 03 menunjukkan hasil analisis data kemampuan berpikir kreatif pada kolom Corrected Model sebesar 0.000 dan lebih kecil dari 0.05. Sehingga dapat disimpulkan bahwa hipotesis nol (H0) ditolak dan hipotesis alternative (Ha) diterima. Hal ini berarti bahwa terdapat pengaruh model pembelajaran Quantum Learning berbantuan peta terhadap kemampuan berpikir kreatif pada Siswa Kelas V SD Di Gugus III Kecamatan Tembuku Kabupaten Bangli Tahun Pelajaran 2018/2019.

Hipotesis yang kedua melakukan analisis data model pembelajaran Quantum Learning berbantuan peta pikiran $(X)$ terhadap hasil belajar IPS $\left(\mathrm{Y}_{1}\right)$, hasil analisis data dapat dilihat pada Tabel 04.

Tabel 04. Tests of Between-Subjects Effects

\begin{tabular}{|l|c|c|c|c|c|}
\hline $\begin{array}{l}\text { Depend } \\
\text { ent } \\
\text { Source Variable }\end{array}$ & $\begin{array}{c}\text { Type III } \\
\text { Sum of } \\
\text { Squares }\end{array}$ & Df & $\begin{array}{c}\text { Mean } \\
\text { Square }\end{array}$ & F & Sig. \\
\hline $\begin{array}{l}\text { Correct Hasil } \\
\text { ed }\end{array}$ & 397.620 & 1 & 397.620 & 37.394 & .000 \\
Belajar & & & & & \\
\hline
\end{tabular}

Tabel 04 menunjukkan hasil hipotesis hasil belajar pada kolom Corrected Model sebesar 0.000 dan lebih kecil dari 0.05. Sehingga dapat disimpulkan bahwa hipotesis nol $(\mathrm{H} 0)$ ditolak dan hipotesis alternative $(\mathrm{Ha})$ diterima. Hal ini berarti bahwa terdapat pengaruh model pembelajaran Quantum Learning berbantuan peta pikiran terhadap hasil belajar IPS pada Siswa Kelas V SD Di Gugus III Kecamatan Tembuku Kabupaten Bangli Tahun Pelajaran 2018/2019.

Hipotesis yang ketiga melakukan analisis data model pembelajaran Quantum Learning berbantuan peta pikiran $(X)$ terhadap kemampuan berpikir kreatif $\left(Y_{1}\right)$ dan hasil belajar IPS $\left(Y_{2}\right)$, hasil analisis data dapat dilihat pada Tabel 05 
Tabel 05. Multivariate Tests ${ }^{b}$

\begin{tabular}{|ll|c|r|}
\hline Effect & F & Sig. \\
\hline Y & Pillai's Trace & $19.699^{\mathrm{a}}$ & .000 \\
& Wilks' Lambda & $19.699^{\mathrm{a}}$ & .000 \\
& Hotelling's Trace & $19.699^{\mathrm{a}}$ & .000 \\
& Roy's Largest Root & $19.699^{\mathrm{a}}$ & .000 \\
\hline
\end{tabular}

Tabel 05 menunjukkan nilai signifikan Pillai's Treace, Wilks'Lambda, Hotelling's Trice, dan Roy's Larget Root sebesar 0.000 dan lebih kecil dari 0,05. Sehingga dapat disimpulkan bahwa hipotesis nol $(\mathrm{HO})$ ditolak dan hipotesis alternative $(\mathrm{Ha})$ diterima. Jadi secara simultan terdapat pengaruh model pembelajaran Quantum Learning berbantuan peta pikiran terhadap kemampuan berpikir kreatif dan hasil belajar IPS pada Siswa Kelas V SD Di Gugus III Kecamatan

Berdasarkan pada hasil pengujian hipotesis yang telah diuraikan sebelumnya ketiga hipotesis yang diajukan pada penelitian ini berhasil menolak hipotesis nol. Berikut adalah rangkuman dari hasil uji hipotesis yang telah dilakukan.

Pengujian hipotesis pertama didapatkan hasil penelitian bahwa terdapat pengaruh kemampuan berpikir kreatif IPS antara siswa yang mengikuti model pembelajaran Quantum Learning berbantuan peta pikiran dan siswa yang tidak dibelajarkan dengan model pembelajaran Quantum Learning yang berbantuan peta pikiran. Berdasarkan uji hipotesis yang telah dilakukan didapatkan hasil bahawa nilai signifikansi sebesar 0,000 dengan nilai Fhitung $=16,585$. Nilai signifikansi yang dihasilkan lebih kecil dari 0,05 , hal tersebut menunjukan bahwa siswa yang mengikuti model Quantum Learning yang berbantuan peta pikiran memiliki kemampuan berpikir kreatif yang lebih baik dari siswa yang tidak dibelajarkan dengan model pembelajaran Quantum Learning yang berbantuan peta pikiran.

Berdasarkan hasil analisis data didapatkan juga bahwa nilai rata-rata kemampuan berpikir kreatif siswa yang mengikuti pembelajaran dengan model Quantum Learning yang berbantuan peta pikiran adalah sebesar 17,00 lebih besar dibandingkan dengan siswa yang tidak dibelajarkan dengan model pembelajaran Quantum Learning yang berbantuan peta pikiran yaitu sebesar 13,48. Hal ini dapat menjadipertimbangan guru agar menjadikan model pembelajaran Quantum Learning berbantuan peta pikiran sebagai salah satu model yang baik digunakan dalam pembelajaran.

Perbedaan kemampuan berpikir kreatif kelas ekperimen dan kelas kontrol terjadi karena perbedaan perlakuan yang diberikan. Pada kelas ekperimen proses pembelajaran menerapkan model pembelajaran Quantum Learning berbantuan peta pikiran sedangkan di kelas kontrol tidak menerapkan model pembelajaran Quantum Learning berbantuan peta. Adanya perbedaan skor tersebut disebabkan oleh Model pembelajaran Quantum Learning merupakan salah satu model pembelajaran yang mendukung terciptanya suatu pembelajaran yang bermakna dan menyenangkan bagi siswa sehingga dapat meningkatkan segala kemampuan serta potensi yang dimiliki oleh masing-masing siswa dengan memanfaatkan cara berpikir siswa. Hal ini sejalan dengan pendapat Kharaerinnida (2017) bahwa model pembelajaran Quantum Learning merupakan model pembelajaran yang menyenangkan dan bermakna yang dapat meningkatkan cara berpikir dan kemampuan siswa.

Tahapan pelaksanaan model pembelajaran Quantum Learning menurut Huda (2014:193) terdiri atas 8 fase yaitu kekuatan ambak, penataan lingkungan belajar, memupuk sikap juara, membebaskan gaya belajar, membiasakan mencatat, mebiasakan membaca, menjadikan anak lebih kreatif, dan melatih kekuatan memori. Adapun temuan yang diperoleh dilapangan pada pelaksanaan Quantum Learning sesuai dengan fase tersebut yaitu sebagai berikut.

Fase keempat yaitu membebaskan gaya belajar, pada fase ini siswa bersama kelompok diberikan kebebasan untuk mencari sumber atau tambahan informasi, sehingga tidak terpaku pada satu gaya belajar saja, dengan berkelompok siswa lebih mudah dalam menyelesaikan 
permasalahan karena adanya interaksi dengan anggota kelompoknya sehingga dapat meningkatkan kemampuan berpikir kreatif siswa. Pembelajaran ini membuat siswa antusius bekerjasama dengan kelompoknya untuk saling berbagi informasi. Hal tersebut diperkuat oleh pendapat Dayantari (2013) menyatakan, pembelajaran yang dilakukan berkelompok siswa akan mudah menemukan dan memahami konsep yang sulit jika mereka saling berdiskusi dengan temannya. Siswa akan secara rutin bekerja dalam kelompok untuk saling membantu memecahkan masalah-masalah dalam pembelajaran.

Fase kelima yaitu mebiasakan mencatat, pada fase ini siswa menuliskan kembali hasil diskusinya bersama kelompok, karena dengan mencatat siswa bisa mengungkapkan kembali apa yang diperoleh atau apa yang sudah ditulis dengan menggunakan bahasa sendiri, sehingga siswa lebih memahami materi yang sudah diberikan selain itu siswa juga diberikan harahan untuk menuliskan hasil diskusi dalam bentuk peta pikiran. Peta pikiran yang dibuat siswa berupa bagan gambar atau simbol dangan catatan-catatan kecil mengenai permasalahan yang diberikan oleh guru sehingga dengan membuat peta pikiran akan membangkitkan ide-ide orisinil dan memicu ingatan yang mudah. Dengan cara ini pembelajaran dapat menyenangkan, dan siswa menjadi lebih kreatif.

Fase kelima yaitu mebiasakan mencatat, pada fase ini siswa menuliskan kembali hasil diskusinya bersama kelompok, karena dengan mencatat siswa bias mengungkapkan kembali apa yang diperoleh atau apa yang sudah ditulis dengan menggunakan bahasa sendiri, sehingga siswa lebih memahami materi yang sudah diberikan. Fase keenam yaitu membiasakan membaca, pada fase ini siswa membacakan hasil diskusi kedepan kelas, dengan membaca siswa bisa meningkatkan pembendaharaan kata dan daya ingat siswa. Fase ketujuh yaitu menjadikan anak lebih kreatif, pada fase ini siswa diberikan pertanyaan terkait materi yang sudah diajarkan, sehingga kemampuan berpikir kreatif siswa dapat dimaksimalkan. Fase kedelapan yaitu melatih kekuatan memori, pada fase ini guru memberikan umpan balik kepada siswa dan guru melakukan pembenaran atau perbaikan bila ada yang kurang tetap terhadap hasil pekerjaan siswa, sehingga siswa dapat mengingat materi yang telah diajarkan dengan baik.

Penggunaan model pembelajaran Quantum Learning mengarahkan siswa untuk aktif dan kreatif, baik dalam berdiskusi, tanya jawab, mencari jawaban, menjelaskan dan menyimak materi yang dijelaskan oleh guru dan teman dengan baik. Dengan suasana kelas yang demokratis, yang saling membelajarkan siswa yang mempunyai pengetahuan lebih, sedangkan yang kurang saling berbaur dan saling mengisi satu dengan yang lainya. Selain model Quantum Learning, agar lebih optimal dipadukan dengan media peta pikiran (mind mapping). Media peta pikiran adalah suatu teknik visual yang dapat menyelaraskan proses belajar dengan cara kerja otak dengan kegiatan mencatat kreatif, efektif, dan secara harafiah yang akan memetakan pikiran-pikiran kita sehingga siswa dengan mudah memahami pelajaran yang di bahas. Dengan cara tersebut, dapat membantu rencana-rencana mereka lebih terarah dengan demikian membuat hidup mereka lebih berarti dan terencana dengan baik. Hal ini sejalan dengan pendapat Tirtawati (2014:3) "para pengguna peta pikiran dapat segera membedakan betapa rencana-rencana mereka lebih terarah dengan demikian membuat hidup mereka lebih berarti". Selain itu dengan cara tersebut dapat membantu siswa meningkatkan hasil belajar dan menciptakan pembelajran yang bermakna bagi siswa, karena siswa dapat lebih mudah mengingat informasi-informasi atau materi-materi yang dipelajari siswa.

Berbeda dengan kelompok kontrol, kegiatan siswa yang tidak mengunakan model pembelajaran Quantum Learning berbantuan peta pikiran yang hanya mengunakan pendekatan saintifik yang berjalan kurang optimal hal tersebut disebabkan karena siswa yang kurang mampu mengaitkan antar materi pada materi IPS dan masih kesulitan dalam mengikuti setiap langkah pembelajaran yang masih perlu diberikan bimbingan khusus.

Berdasarkan hasil analisis dan temuan dalam penelitian ini yang sesuai dengan penelitian ini, sehingga dapat disimpulkan bahawa terdapat pengaruh yang signifikan model pembelajaran Quantum Learning berbantuan peta pikiran terhadap kemampuan berpikir kreatif pada Siswa Kelas V SD Semester Genap Di Gugus III Kecamatan Tembuku Kabupaten Bangli Tahun Pelajaran 2018/2019. 
PIPS, Vol. 3 No. 1, Bulan April Tahun 2019

ISSN:2614-8366

Pengujian Hipotesis kedua didapatkan hasil Fhitung sebesar 37.394 dengan nilai $p=0,000<$ 0,05 . Hasil tersebut menunjukan bahwa hipotesis nol yang berbunyi Tidak terdapat pengaruh model pembelajaran Quantum Learning berbantuan peta pikiran terhadap hasil belajar IPS pada Siswa Kelas V SD Semester Genap Di Gugus III Kecamatan Tembuku Kabupaten Bangli Tahun Pelajaran 2018/2019, ditolak dan hipotesis alternative diterima.

Skor rata-rata siswa yang dibelajarkan menggunakan model Quantum Learning berbantuan peta pikiran adalah 18,68 sedangkan skor rata-rata siswa yang tidak dibelajarkan dengan model pembelajaran Quantum Learning yang berbantuan peta pikiran yaitu sebesar 13,04. Dari hasil tersebut dapat disimpulkan bahwa hasil belajar IPS siswa yang dibelajarkan dengan model pembelajaran Quantum Learning berbantuan peta pikiran menunjukan hasil yang lebih baik dari pada siswa yang tidak dibelajarkan dengan model pembelajaran Quantum Learning berbantuan peta pikiran.

Perbedaan hasil belajar kelas ekperimen dan kelas kontrol terjadi karena perbedaan perlakuan yang diberikan. Pada kelas ekperimen proses pembelajaran menerapkan model pembelajaran Quantum Learning berbantuan peta pikiran sedangkan di kelas kontrol tidak menerapkan model pembelajaran Quantum Learning berbantuan peta pikiran desebabkan oleh beberapa faktor. Faktor pertama, pada proses pembelajaran Quantum Learning menekankan suasana yang kondusif dan menyenangkan. Hal ini sejalan dengan penjelasan Silbermen (2009) bahwa pembelajaran yang semakin melibatkan aktifitas peserta didik secara aktif akan mampu meningkatkan daya ingat serta keterampilan peserta didik dalam memecahkan masalah. Suasana pembelajaran yang menyenangkan dan keterlibatan siswa dalam proses pembelajaran akan menjadikan pembelajaran lebih efektif. Faktor kedua, pada proses pembelajaran Quantum Learning menekankan keberagaman dan kebebasan, siswa diberikan kebebasan menggali informasi dalam proses diskusi untuk menyelesaikan permasalahan-permasalahan yang diberikan oleh guru, selain itu siswa dibiasakan untuk mencatat dan membaca hasil diskusi, sehingga siswa dapat mengungkapkan kembali informasi yang diperoleh dan meningkatkan pemahaman terhadap materi yang diberikan.

Faktor selanjutnya yang menyebabkan adanya perbedaan hasil belajar IPS adalah penggunaan media pembelajaran pada kelas eksperimen yaitu media peta pikiran. Penggunaan media pembelajaran dapat merangsang minat dan motivasi siswa dalam mengikuti pembelajaran. Pembelajaran mind mapping pada hakikatnya adalah salah satu sistem yang memanfaatkan otak sebagai pusat pemerolehan informasi oleh siswa dengan cara memetakan pikirannya terhadap informasi yang diperoleh sehingga siswa lebih mudah memahami pembelajaran. Sejalan dengan pendapat Busan (2013:4) "peta pikiran (mind mapping) adalah cara mencatat kreatif, efektif, dan secara harfiah yang akan memetakan pikiran-pikiran kita". Berbeda dengan kelas yang tidak menggunakan model pembelajaran Quantum Learning berbantuan peta pikiran yang masih berpusat pada guru (teacher centered). Hal ini sejalan dengan pendapat Menurut Santyasa, (2005:37) "pembelajaran konvensional bersifat teacher directed". Mengajar yang bersifat langsung lebih menekankan pada penyampaian pengetahuan kepada siswa sehingga kegiatan pembelajaran lebih berpusat pada guru.

Hipotesis ketiga didapatkan hasil bahwa nilai signifikansi lebih kecil dari $0,05(p=0,000<0,05)$.

Uji Manova tersebut dilakukan untuk mengetahui pengaruh model pembelajaran Quantum Learning berbantuan peta pikiran terhadap kemampuan berpikir kreatif dan hasil belajar IPS. Kriteria pengujian hipotesis yang digunakan adalah apabila $\mathrm{p}<0,05$ maka $\mathrm{HO}$ ditolak dan $\mathrm{Ha}$ diterima, sebaliknya jika $\mathrm{p}>0,05$ maka HO diterima dan Ha ditolak. Hasil uji Manova diatas menunjukkan bahwa nilai signifikansi menunjukan angka lebih kecil dari 0,05 yang berarti bahwa $\mathrm{HO}$ ditolak. Oleh karena itu hipotesis nol yang menyatakan bahwa secara simultan tidak tedapat pengaruh model pembelajaran Quantum Learning berbantuan peta pikiran terhadap kemampuan berpikir kreatif dan hasil belajar IPS pada Siswa Kelas V SD Semester Genap Di Gugus III Kecamatan Tembuku Kabupaten Bangli Tahun Pelajaran 2018/2019, ditolak dan hipotesis alternative diterima.

Model pembelajaran yang inovatif, menyenangkan, dan berorientasi pada peserta didik cenderung meningkatkan daya ingat siswa, karena siswa langsung merasakan dan mengerjakan 
sendiri. Sesuai dengan fase ketujuh dan kedelapan pada Quantum Learning, siswa dapat menghasilakan ide-ide yang segar dalam proses pembelajaran dan melatih kekuatan memori siswa sehingga pembelajaran menjadi lebih efektif. Daya ingat yang tinggi akan berpengaruh terhadap kemampuan berpikir kreatif dan hasil belajar IPS siswa. Model pembelajaran Quantum Learning merupakan model pembelajaran yang inovatif, menyenangkan dan berorientasi pada peserta didik (student centered). Hal ini diperkuat oleh pendapat Huda, (2014:192) "Quantum Learning merupakan model pembelajaran yang membiasakan belajar menyenangkan”. Penerapan model ini diharapkan dapat meningkatkan minat belajar siswa sehingga pada akhirnya siswa dapat meningkatkan hasil belajar secara menyeluruh. Lingkungan belajar yang menyenangkan dapat menimbulkan motivasi pada diri siswa sehingga secara langsung dapat mempengaruhi proses belajar mereka. Temuan tersebut Sejalan dengan pendapat Pratiwi (2017) dengan model pembelajaran Quantum Learning siswa menjadi lebih termotivasi dalam belajar karena belajar akan menjadi suatu proses yang menyenangkan dan bermakna sehingga peserta didik akan dapat memahami materi yang diajarkan oleh guru. Pembelajaran Quantum Learning memandang bahwa segala potensi diri, kemampuan pikiran, daya motivasi, dan sebagainya yang dimiliki oleh siswa dapat berkembang seacara maksimal. Selain model pembelajaran pemilihan media juga sangat diperlukan salah satunya yaitu media peta pikiran. Penggunaan media peta pikiran dalam pembelajarn IPS dapat menemukan cara termudah untuk menempatkan informasi dan cara mencatat yang kreatif, efektif, dan secara harafiah akan memetakan pikiran-pikiran kita. Dengan cara tersebut dapat membantu siswa meningkatkan hasil belajar IPS dan kemampuan berpikir kreatif siswa serta menciptakan pembelajaran yang bermakna bagi siswa, karena siswa akan lebih mudah mengingat informasi-informasi atau materi-materi yang dipelajari oleh siswa tersebut. Hasil temuan yang diperoleh dilapangan menunjukan pada kelompok siswa yang mengikuti model pembelajaran Quantum Learning, siswa terlihat sangat antusias dalam mengikuti pembelajaran, menunjukan sikap respek terhadap pembelajaran IPS dan kreativitas pada saat membuat mind mapping. Dengan demikian pemahaman dan ingatan siswa terhadap pembelajaran IPS menjadi kuat dan bertahan lama, hal ini akan berpengaruh positif terhadap hasil belajar siswa.

Berbeda dengan pembelajaran IPS yang tidak menggunakan model pembelajaran Quantum Learning bebantuan peta pikiran menunjukan bahwa dalam proses belajar lebih banyak belajar dengan metode ceramah. Hal ini terlihat bahwa pembelajaran menjadi kurang menyenangkan dan bermakna sehingga kurang meningkatkan kemampuan berpikir kreatif dan hasil belajar IPS siswa karena guru lebih banyak mendominasi kegiatan pembelajaran. Pembelajaran seperti itu akan membuat siswa merasa jenuh dan membosankan.

\section{SIMPULAN DAN SARAN}

Berdasarkan hasil penelitian dan pembahasan, Uji Test Of Between-Subjects Effects didapatkan nilai signifikansi kemampuan berpikir kreatif pada kolom Corrected Model sebesar 0.000 dan lebih kecil dari 0.05. dapat ditarik kesimpulan bahwa terdapat pengaruh model pembelajaran Quantum Learning berbantuan peta pikiran terhadap kemampuan berpikir kreatif pada Siswa Kelas V SD Di Gugus III Kecamatan Tembuku Kabupaten Bangli Tahun Pelajaran 2018/2019.

Hasil penelitian dan pembahasan yang mengunakan uji Test of Between Subject Effect didapatkan nilai signifikansi hasil belajar IPS pada kolom Corrected Model sebesar 0.000 dan lebih kecil dari 0.05. sehingga dapat disimpulkan bahwa terdapat pengaruh model pembelajaran Quantum Learning berbantuan peta pikiran terhadap hasil belajar IPS pada Siswa Kelas V SD Di Gugus III Kecamatan Tembuku Kabupaten Bangli Tahun Pelajaran 2018/2019.

Hasil penelitian dan pembahasan, menunjukkan nilai signifikansi Pillai's Treace, Wilks'Lambda, Hotelling's Trice, dan Roy's Larget Root sebesar 0.000 dan lebih kecil dari 0,05. Jadi secara simultan terdapat pengaruh model pembelajaran Quantum Learning berbantuan peta pikiran terhadap kemampuan berpikir kreatif dan hasil belajar IPS pada Siswa Kelas V SD Di Gugus III Kecamatan Tembuku Kabupaten Bangli Tahun Pelajaran 2018/2019. Dengan demikian penerapan model pembelajaran Quantum Learning berbantuan peta pikiran pengaruh positif 
terhadap kemampuan berpikir kreatif dan hasil belajar IPS siswa kelas V SD Di Gugus III Kecamatan Tembuku Kabupaten Bangli Tahun Pelajaran 2018/2019.

Berdasarkan temuan-temuan dalam penelitian ini, dapat disampaikan saran-saran sebagai berikut: (1) Kepada Siswa, Siswa-siswa di SD agar lebih aktif dalam mengikuti pembelajaran dan terus mengembangkan pemahamannya dengan membangun sendiri pengetahuan tersebut melalui pengalaman, (2) Kepada Guru, guru IPS SD agar lebih inovatif dalam memilih model pembelajaran dan media pembelajaran yang akan diterapkan pada proses pembelajaran. Sehingga pembelajaran lebih efektif dan menarik, tidak monoton, serta dapat meningkatkan Kemampuan berpikir kreatif dan hasil belajar IPS siswa, (3) Kepada Kepala Sekolah, Kepala Sekolah disarankan agar dapat menciptakan kondisi yang mampu mendorong para guru untuk mencoba menerapkan model pembelajaran Quantum Learning berbantuan peta pikiran dalam pembelajaran IPS khususnya dan mata pelajaran lain pada umumnya dalam upaya meningkatkan kemampuan berpikir kreatif dan hasil belajar IPS siswa, (4) Kepada Peneliti Lain, Peneliti yang berminat untuk mengadakan penelitian lebih lanjut tentang model pembelajaran Quantum Learning berbantuan peta pikiran dalam bidang ilmu lainnya. Penelitian ini sebagai bahan pertimbangan untuk perbaikan dan penyempurnaan penelitian yang akan dilaksanakan.

\section{DAFTAR RUJUKAN}

Agung, A.A Gede. 2016. Statistik dasar Untuk pendidikan. Yogyakarta: Deepublish.

Buzan, Tony. 2013. Buku Pintar Mind Map. Jakarta: PT Gramedia Pustaka Utama.

Candiasa, I Made. 2010c. Statistik Multivariat Disertai Aplikasi Statistik SPSS. Singaraja: Unit Penerbitan Universitas Pendidikan Ganesha.

Darmayoga, I Wayan. 2013. "Pengaruh Implementasi Metode Mind Mapping Terhadap Hasil Belajar IPS Ditinjau dari Minat Siswa Kelas IV SD Sathya Sai Denpasar".Tersedia pada http://pasca.undiksha.ac.id/ejournal/index.php/jurnalpendas/issue/archive (diakses tanggal 09 Januari 2019)

Huda, Miftahul. 2014. Model -model Pengajaran dan Pembelajaran Isu-isu Metodis dan Paradigmatis. Yogyakarta: Pustaka Pelajar

Kharaerinnida. 2017. "Pengaruh Penerapan Model Pembelajaran Quantum Terhadap Kemampuan Berpikir Kreatif dan Hasil Belajar IPA Siswa Kelas IV Sekolah Dasar Gugus Ir. Soekarno Kecamatan Denpasar Selatan". e-Journal Program Pascasarjana Universitas Pendidikan Ganesha. Program Studi Pendidikan Dasar Volume 7, Nomor 1.

Munandar, Utami. 2004. Pengembangan Kreativitas Anak Berbakat. Jakarta: Rineka Cipta.

Pratiwi, Intan. (2017). "Pengaruh Model Pembelajaran Quantum Learning Berbantuan Peta Konsep Terhadap Hasil Belajar IPA Siswa Kelas V". e-Journal PGSD Universitas Pendidikan Ganesha. Mimbar PGSD Volume 5, Nomor 2.

Purnamiati, Dwi, dkk. (2017). "Pengaruh Model Pembelajaran Kooperatif Tipe Mind Mapping Terhadap Kreativitas Dan Prestasi Belajar IPA Siswa Kelas VI SD No. 3 Benoa Kabupaten Badung". e-Journal Program Pascasarjana Universitas Pendidikan Ganesha. Program Studi Pendidikan Dasar Volume 7, Nomor 1.

Purnamiati, Dwi, dkk. (2017). "Pengaruh Model Pembelajaran Kooperatif Tipe Mind Mapping Terhadap Kreativitas Dan Prestasi Belajar IPA Siswa Kelas VI SD No. 3 Benoa 
Kabupaten Badung". e-Journal Program Pascasarjana Universitas Pendidikan Ganesha. Program Studi Pendidikan Dasar Volume 7, Nomor 1.

Sanjaya, Wina. 2006. Strategi Pembelajaran Berorientasi Standar Proses Pendidikan. Jakarta: Kencana Prenada Media.

Susanto, Ahmad. 2013. Teori Belajar dan Pembelajaran di Sekolah Dasar. Jakarta: Kencana.

Thobroni. 2015. Belajar dan Pembelajaran. Yogyakarta: Ar-Ruzz Media

Tirtawati, Ratna. (2014). "Pengaruh Pembelajaran Kuantum (Quantum Learning) dan Peta Pikiran (Mind Mapping) Terhadap Keterampilan Berpikir Kreatif Dan Hasil Belajar Biologi Siswa SMA". e-Journal Program Pascasarjana Universitas Pendidikan Ganesha. Program Studi IPA Volume 4. 